\title{
GLAGIOLOGICAL RECONNAISSANCE OF AN ICE CORE DRILLING SITE, PENNY ICE CAP, BAFFIN ISLAND
}

\author{
By G. Holdsworth
}

(National Hydrology Research Institute, Snow and Ice Division, Environment Canada, Calgary, Alberta T3A OX9, Canada)

\begin{abstract}
A site situated close to the main divide of the Penny Ice Cap, Baffin Island was occupied in 1979 for the purpose of determining the suitability of this ice cap for providing proxy climatic data and other environmental time series for a span of $10^{4}$ a. A $20 \mathrm{~m}$ core was extracted and analysed for stable oxygen isotopes, tritium concentration, $\mathrm{pH}$, electrolytic conductivity, major ion concentrations, and particulate concentration. An adjacent dedicated shallow core was analysed for pollen content to determine if a significant seasonal variation in the pollen rain existed. From these measurements, and from the observations made on the stratigraphic character of the core, the mean net accumulation rate over the approximately 30 year period covered by the core is found to be about $0.43 \mathrm{~m}$ water equivalent per year. This is in agreement with a single value determined 26 years earlier at a nearby site (Ward and Baird, 1954). The mean annual temperature in the bore hole was found to be close to $-14.4^{\circ} \mathrm{C}$, possibly some 2-5 deg warmer than the expected mean annual surface air temperature at the site. This difference is due to the expulsion of latent heat upon freezing of melt water at depth in the snow-pack which gives rise to the many ice layers observed in the core. The percentage thickness of ice layers per year may be correlated with summer temperatures.

Total ice depths were measured using a $620 \mathrm{MHz}$ radar echo-sounder. In the vicinity of the divide, over an area of $1 \mathrm{~km}^{2}$, the ice depths vary from about 460 to $515 \mathrm{~m}$. These values compare favourably with values determined from an airborne radar depth-sounding flight carried out over the ice cap by a joint U.S.-Danish mission operating out of S $\phi$ ndre Stromfjord, Greenland. The data suggest that the ice-cap divide would be a worthwhile location to deep core drill with an expected useful coverage of at least the Holocene period
\end{abstract}

RÉsumÉ. Reconnaissance glaciologique d'un sile de forage dans la glace sur la calolte glaciaire de Penny dans l'fle de Baffin. Un site proche de la chaîne principale de la calotte glaciaire de Penny dans l'île de Baffin a été occupé en 1979 pour étudier la possibilité d'utiliser cette calotte glaciaire pour obtenir des données climatiques proches et d'autres séries dans le temps su l'environnement sur un laps de temps de $10^{4}$ ans. Une carotte de $20 \mathrm{~m}$ a été extraite et analysée pour les isotopes stables de l'oxvgène, la concentration en tritium, le $\mathrm{pH}$, la conductivité électrolytique, la concentration en ions majeurs et la teneur en particules. Une carotte adjacente a subi des analyses polliniques pour déterminer s'il y a une variation saisonnière significative des retombées de pollen. De ces mesures et des observations faites sur caractère stratigraphique de l'échantillon on a conclu que l'accumulation moyenne annuelle sur la période d'environ 30 ans couverte par la carotte est d'environ $0,43 \mathrm{~m}$ d'équivalent en eau par an. Ceci est cohèrent avec une valeur singulière déterminée 26 ans auparavant en un site voisin Ward et Baird, 1954 . La température moyenne annuelle dans le forage était proche de $-14,4^{\circ} \mathrm{C}$ probablement quelque $2,5 \mathrm{deg}$ plus chaude que la température

\section{INTROOUCTION}

Previous known glaciological research on the Penny Ice Cap, south-east Baffin Island (Fig. 1) was carried out in 1953 by an Arctic Institute of North America expedition (Baird and others, 1953; Ward and Baird, 1954 ) and by Weber and Andrieux (1970). The former publication reports on measurements confined to the far south-east sector of the ice cap, about $25 \mathrm{~km}$ distant from and possibly lower than the site herein described. The latter publication gives ice depth data to within $11 \mathrm{~km}$ to the north-west of the present site.

Four low domes, each reaching to about $1990 \mathrm{~m}$ above sea-level, exist in the east-central part of the ice cap (Fig. 2). The site, occupied in April-May 1979 , lies between the two most northerly domes, but nearer the southern and higher one of the two. (The intention was to occupy this latter dome, but in landing by aircraft, the surface relief was lacking in contrast and a misidentification of position was moyenne annuelle de l'air attendue en surface à ce site. Cette différence est due à l'expulsion de chaleur latente de regel d'eau de fusion en profondeur dans le manteau neigeux qui donne la plus grande part des niveaux de glace observés dans la carotte. La proportion de l'épaisseur des niveaux de glace créée chaque année peut être corrélée avec les températures d'été. Les épaisseurs totales de glace ont été mesurées avec une sonde à écho radar à $620 \mathrm{MHz}$. Dans le voisinage de la chaîne centrale sur une surface de $1 \mathrm{~km}^{2}$ les épaisseurs de glace varient d'environ 460 à $515 \mathrm{~m}$. Ces valeurs se comparent correctement aux valeurs déterminées par un sondage radar aérien effectué sur l'ensemble de la calotte glaciaire par une mission commune U.S.-danoise opérant depuis le S $\phi$ ndre Str $\phi$ mfjord, Groenland. Les données suggèrent que la chaîne centrale de la calotte glaciaire pourrait être un bon emplacement pour un forage profond avec l'espoir de l'utiliser pour couvrir au moins la période de l'holocène.

Zusammenfassung. Glaziologische Erkundung einer Kernbohrstelle auf dem Penny Ice Cap, Baffin Island. Eine Stelle nahe der Haupteisscheide des Penny Ice Cap, Baffin Island wurde 1979 mit dem Ziel besetzt, die Eignung dieser Eiskappe zur Gewinnung repräsentativer Klimadaten und anderer umweltrelevanter Zeitserien über die letzten $10^{4}$ Jahre zu bestimmen. Ein $20 \mathrm{~m}$ langer Bohrkern wurde gezogen und auf stabile Sauerstoffisotope, TritiumKonzentration, pH-Wert, elektrolytische Leitfähigkeit, grössere IonenKonzentrationen und besondere Konzentrationen untersucht. Ein dicht danebenliegender, kurzer Bohrkern wurde auf seinen Pollengehalt untersucht, um zu erfahren, ob eine signifikante jahreszeitliche Schwankung im Pollenregen besteht. Aus diesen Messungen und aus den Beobachtungen über den stratigraphischen Aufbau des Bohrkerns wurde die mittlere Nettoakkumulation über die etwa 30 Jahre, die der Bohrkern überbrückt, zu c. 0,43 m Wasser pro Jahír bestimmt. Dies stimmit mit einem Einzelwert überein, der vor 26 Jahren an einer nahe benachbarten Stelle gewonnen wurde (Ward und Baird, 1954). Die mittlere Jahrestemperatur in dem Bohrloch ergab sich nahe an $-14.4^{\circ} \mathrm{C}$, mögicherweise etwa 2-5 deg wärmer als die erwartete mittlere Jahrestemperatur der Luft an der Bohrstelle. Diese Differenz ist mit dem Austritt latenter Wärme beim Gefrieren von Schmelzwasser in der Tiefe der Schneedecke zu erklären; dabei entstehen die vielen Eisschichten, die im Bohrkern zu finden waren. Die prozentuale Dicke der Eisschichten pro Jahr dürfte mit den Sommertemperaturen korreliert sein. Die Gesamtdicke des Eises wurde mit einem $620 \mathrm{MHz}-\mathrm{Radarecholot}$ gemessen. In der Nachbarschaft der eisscheide, in einem Gebiet von $1 \mathrm{~km}^{2}$, schwanken die Fisdicken Zwischen etwa 460 und $515 \mathrm{~m}$. Diese Werte passen sehr gut zu jenen, die bei einem Radarechoflug über der Eiskappe, ausgeführt im Rahmen einer gemeinsamen Unternehmung der USA und Dänemarks von Sondre-Strom-Fjord in Grönland aus, ermittelt wurden. Die Daten lassen vermuten, dass die Eisscheide ein geeigneter Ort für eine tiefe Kernbohrung wäre, deren Datenausbeute zumindest das Holozän überdecken würde.

made. Because of limited surface mobility, it was decided to establish the reconnaissance camp at the landing site about $500 \mathrm{~m}$ to the east of the main icecap divide).

The present site reconnaissance was carried out to determine if useful paleo-environmental information might be extracted from the ice cap and where a suitable deep drill site might exist. Of prime interest was the potential of the core for yielding proxy climatic and other atmospheric data, and, if positive, what useful time span was likely to be covered. Such data would be useful input to previous climatological modelling studies for Baffin Island (Barry and Fogarasi, 1968; Andrews and Barry, 1972; Andrews and others, 1980), as well as Holocene glacier fluctuations and palynological studies over the same interval (Miller, 1973).

Climatic data from this area, in conjunction with similar data from southern Greenland (Dansgaard and others, 1975) would he extremely useful in long-term studies related to the behaviour of the Icelandic. 


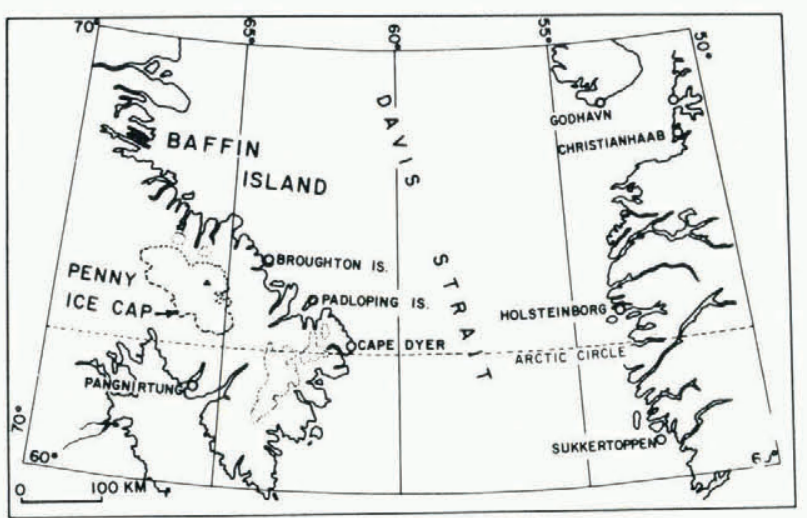

Fig.1. Map showing south-easterm Baffin Island and the location of Penny Ice Cap. Broughton Island and Cape Dyer are two sources of instmontal climatic data in the area.

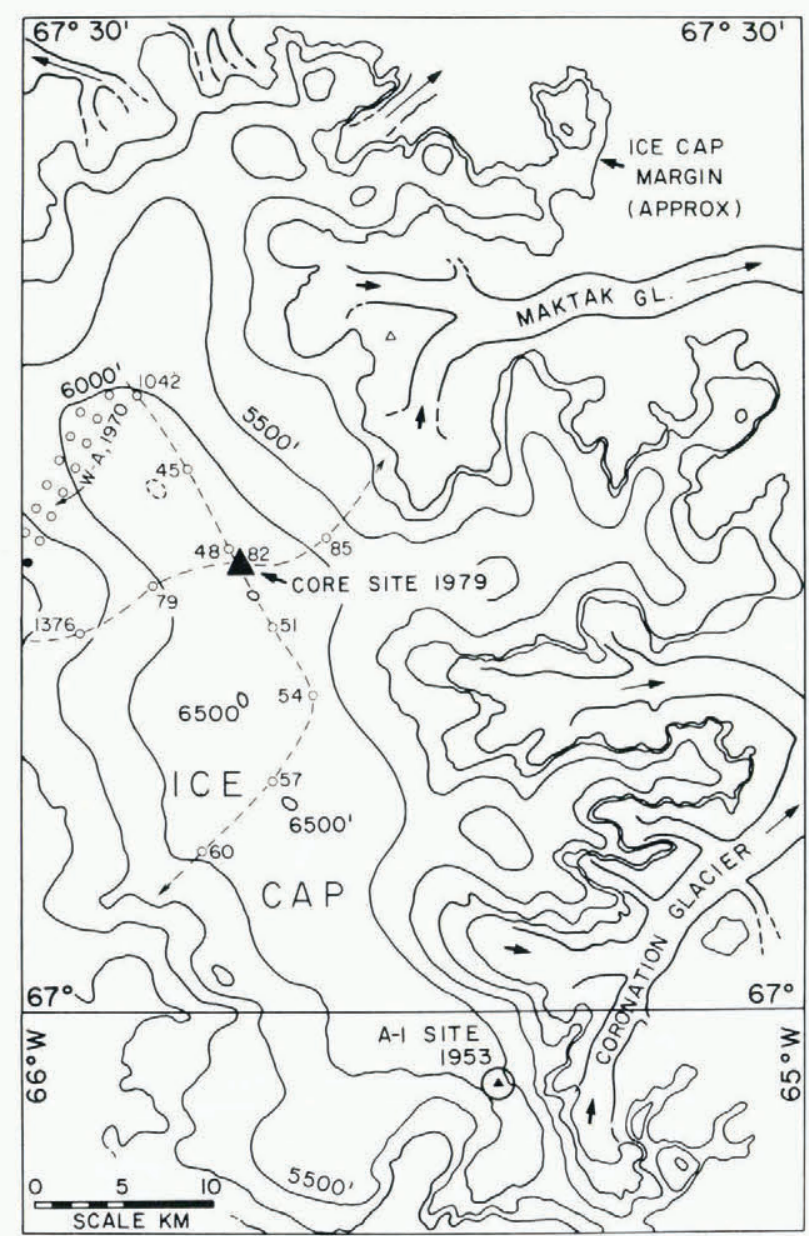

Fig.2. East-central section of the Penny Ice Cap show ing the location of the 1979 field camp and core site. The highest part of the ice cap is defined by four broad domes rising above the $6500 \mathrm{ft}(1980 \mathrm{~m})$ contour. Site $A-1$, to the south-east was occupied in 1953 by an Aretic Institute of North America Party. The traverse and pole positions of Weber and Andrieux (1970) are also marked: W-A,1970. Two flight tracks of the airbome radar operation are shown with identifying numbers (see profiles in Fig. 1?).
Low. This major climatic feature is of extreme importance for understanding the climate of the North Atlantic area and adjacent regions.

From available field evidence (Dyke and others, 1982) it may be assumed that the present location of the Penny Ice Cap divide is not significantly different from its location at any time over the last $10^{4}$ years. From knowledge of the position of the ice margin during most of that time, it is unlikely that the ice thickness near the divide has changed by more than a few per cent over that time. This allows a relatively straightforward interpretation of an ice core that might be retrieved by drilling through the divide.

\section{SITE SURVEY}

A site, about $500 \mathrm{~m}$ east of the divide of the ice cap, at lat. $67^{\circ} 14^{\prime} \mathrm{N}$. , long. $65^{\circ} 43^{\prime} \mathrm{W}$., altitude $1975 \mathrm{~m}$ (Fig. 2) was occupied from 24 April to 14 May 1979. During this time, a continuous $20 \mathrm{~m}$ firn and ice core was recovered for oxygen-isotope and other analyses, a $6 \mathrm{~m}$ core was obtained for pollen studies, an accumulation pole array was established, and some ice depth soundings were carried out. Ice temperatures were monitored in the $20 \mathrm{~m}$ bore hole. During this time, some limited meteorological measurements were also recorded.

The camp was used as a reference point for an airborne radar ice thickness survey of the complete ice cap, carried out on 9 May. Results of this survey will be published separately.

\section{Site characteristics}

The site is located in the percolation zone (Paterson, 1981) and most years, except the very coldest, are characterized by moderate to high ice-layer formation. Spring and winter snow is quite heavily covered by sastrugi formed by the intense storms which occur on the ice cap.

\section{Core retrieval and processing}

Core drilling was accomplished with a standard SIPRE corer. The core was immediately placed into plastic tubing and stored in a transit case set in a snow pit covered by an igloo. The core was later air freighted to 0ttawa. Apart from a short section below the base of the pit, which was poorly packaged and labelled, the core is considered good and will be referred to in the text as complete. A separate $6 \mathrm{~m}$ core was retrieved for pollen analysis, which has now been completed (a paper on this is in preparation by S. Short and G. Holdsworth). This study showed that significant seasonal variations in pollen rain do exist at this site but that in order to obtain a satisfactory spectrum showing clear summer-winter oscillations (i) a larger horizontal cross-sectional sample area is required and (ii) cutting of samples should be along summer-winter boundaries. This latter requirement can only be achieved after other analyses of the core have been carried out.

Pollen data could be usea as an independent check on stratigraphic interpretation. More important, however, is the potential of pollen variation data (in conjunction with oxygen isotope data) for throwing light on air-mass circulation patterns.

Some core processing was carried out in the science laboratory in Frobisher Bay, the remainder was done in the Environment Canada cold rooms in ottawa.

\section{CORE ANALYSES}

All core handling was carried out with double plastic gloves and a face mask. Samples were cut with a cleaned stainless-steel saw and then placed in "whirl-pak" plastic bags for melting.

Core stratigraphic interpretation was carried out simultaneously with sample preparation. The densities of the firn, iced firn, or ice layers were determined, 


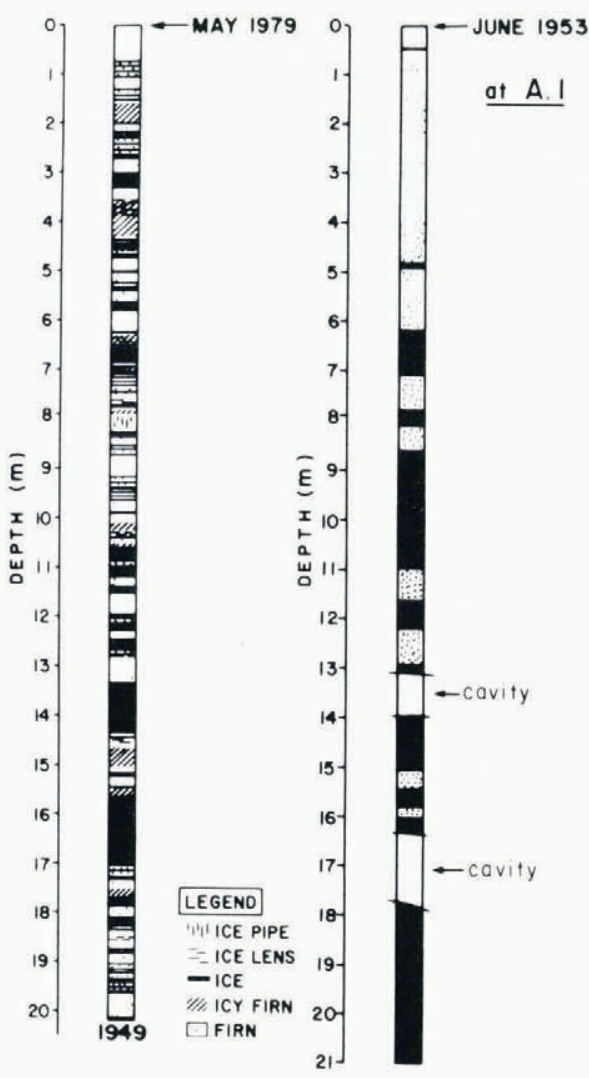

(a)

(b)

Fig.3. Visual core stratigraphy for (a) the core retrieved in 1979 and (b) the core retrieved in 1953 at site $A-1$. Upper blank sections are snow, lower blank sections in (b) are cavities. Note that in (b) the apparent lack of detail compared with (a) is due to interpretative differences. The net length of the 1953 core is $18.5 \mathrm{~m}$.

where possible, by weighing, in air, selected samples of the core. The gross stratigraphy of the core, and that of an earlier core (Ward and Baird, 1954) are shown in Figure 3.

Analyses for oxygen isotopes were carried out on 200 samples cut at $10 \mathrm{~cm}$ intervals along the complete core. The measurements were done at the Geophysical Isotope Laboratory, Copenhagen, and are shown in Figure 4.

Tritium concentration measurements were made on the water remaining from the oxygen isotope sampling. These measurements were carried out at the Radiation Protection Bureau, 0ttawa. The results are shown in Figure 5 .

Analysis of the complete core for conductivity and $\mathrm{pH}$ was carried out with special attention being paid to the depth interval $9.5 \mathrm{~m}$ to $12.5 \mathrm{~m}$ which contains a large electrolytic conductivity disturbance (Fig. 6) thought initially, but erroneously, to be caused by the Mt Agung volcanic eruption of March 1963.

The $\mathrm{pH}$ measurements presented in Figure 7 represent two independent sets of data obtained from separately cut sequences and using different $\mathrm{pH}$ meters. The major trends in both $\mathrm{pH}$ and electrolytic conductivity are all reproducible.

Conductivity and particulate analyses were carried out on a quarter section of the core, at the laboratories of the Polar Continental Shelf Project (PCSP), Ottawa. Sample intervals were irregular as a result of separating firn from ice. Most sample lengths were close to $5 \mathrm{~cm}$. Figure 8 shows that this procedure resulted in a much higher variation in concentration values compared with the values shown in Figure 6 .
Some limited chemical analyses were carried out. Figure 9 shows the complete $\mathrm{Na}^{+}$concentration profile. The analyses were done at the Environment Canada Laboratories (ECL), Ottawa. Despite the fact that no ultra-clean procedures could be adhered to, the values for most of the core are at the same general level as those given by Busenberg and Langway (1979) for some Greenland sites, and are therefore thought to be free of gross contamination.

In order to examine the interval 10-12 $\mathrm{m}$ in more detail, remaining core was recut at $10 \mathrm{~cm}$ intervals and resubmitted to ECL for analysis for $\mathrm{Na}^{+}, \mathrm{K}^{+}, \mathrm{Ca}^{2+}$ and $\mathrm{Mg}^{2+}$ (Fig. 10). The levels of $\mathrm{Na}^{+}$are consistent with those of Figure 9.

As a final check, principal cation analyses were performed on the samples submitted to the PCSP laboratory. The results (Fig. 11) show much greater variation in adjacent values than do the corresponding data in Figure 10. This is hecause the sampling interval for the PCSP samples was much less than the previous arbitrary $10 \mathrm{~cm}$ sampling interval. Generally, the higher ionic concentrations in Figure 11 apply to the solid ice samples. This is an expected result, since salts would tend to be leached out of snow and concentrated in the refrozen melt water. There are, however, significant differences between the means of the corresponding data sets, and the reasons for this are assumed to be related to sample preparation and measurement. Compared with Figure 11, the data set in Figure 10 has lower means over the interval $10-12 \mathrm{~m}$. These are for $\mathrm{Na}^{+}, 0.08 ; \mathrm{K}^{+}, 0.013 ; \mathrm{Ca}^{2+}$, 0.053 ; and $\mathrm{Mg}^{2+}, 0.024$ (p.p.m.).

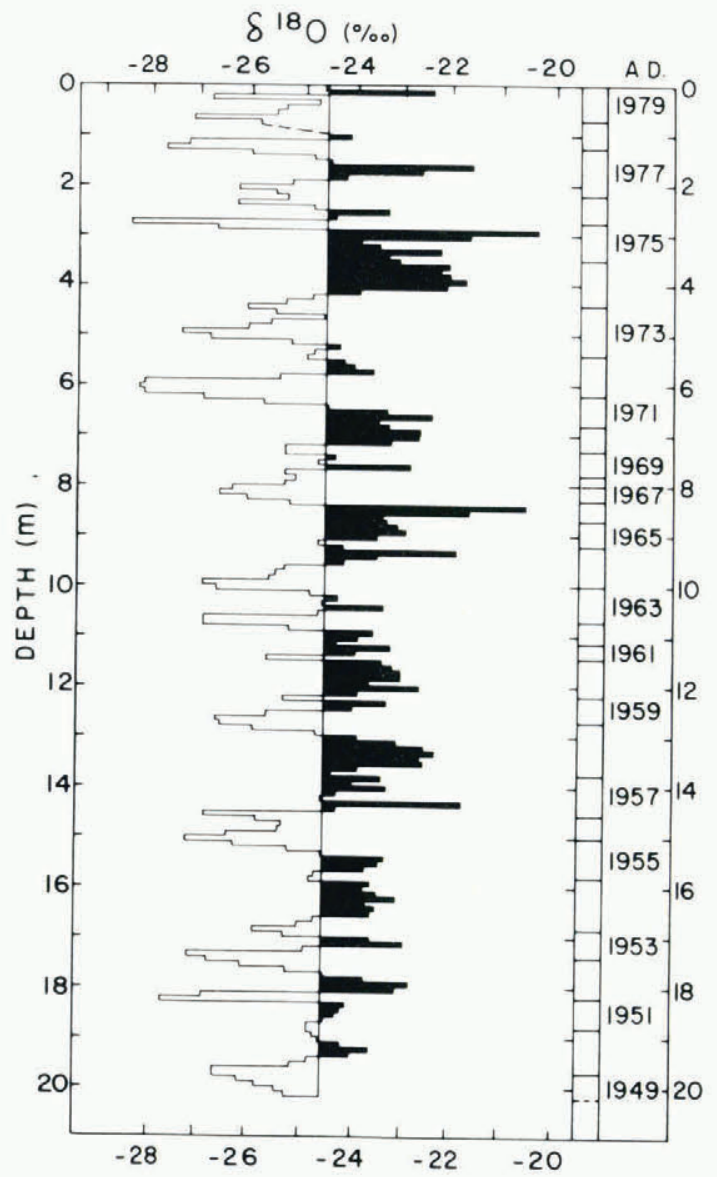

Fig.4. Depth variations of $\delta^{180}$ with a sample inter val of $10 \mathrm{~cm}$. Mean $\delta$ value is $-24.6 \%$. Seasonal vamiations in $\delta$ are locked in and have been used, in conjunction with other time control methods (tritium concentration, ion chemistry), to derive the time scale shown. Data were provided by the Geophysical Isotope Laboratory, Copenhagen (W. Dansgaard). 


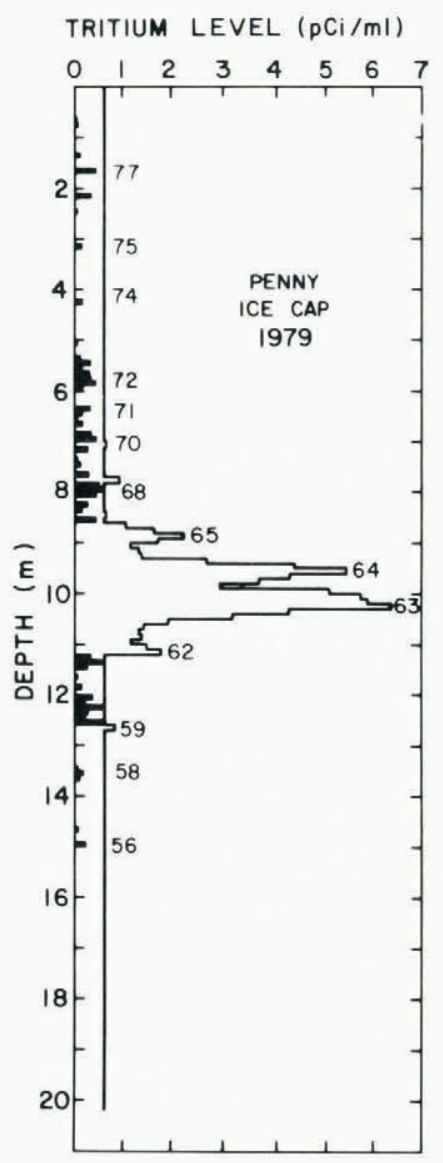

Fig.5. Depth variation of tritium concentration in the ice core, with a sample interval of $10 \mathrm{~cm}$. Levels below one standard deviation $(0.6 \mathrm{p}(\mathrm{i} / \mathrm{ml})$, marked in black, have been used, since they correspond with peaks in gross $\mathrm{B}$ activity variations seen in core samples from the Yukon Territory. Data were provided by the Radiation Protection Bureau, Ottawa (F. Prantl, D. Meyerhof).

\section{DISCUSSION OF CORE ANALYSES}

Isotope data

The $\delta^{18} 0$ plot (Fig. 4) shows that seasonal $\delta$ variations are locked in, and that the core, when interpreted with the help of other data, covers a period of about 30 years. This time scale has been calibrated absolutely at several points, using the tritium concentration diagram (Fig. 5). This shows calibrating peaks in 1956, 1958, 1959, 1962, 1963 (corresponding to pre-moratorium atmospheric nuclear warhead tests), 1964, 1965, 1966, 1968, and 1969. Although it has only been demonstrated at a few points, it is assumed that the isotopic seasons are everywhere in phase with climatic seasons. Prior to 1956, there may be an error of \pm 1 year in the time scale.

\section{General stratigraphy}

The base of the core is seen to be penetrating snow deposited in about 1949 . The interesting result is that a splice may now be made with an 18.5 m core extracted 26 years previously, from a site of similar altitude, $25 \mathrm{~km}$ to the south-east (Location A-1, Fig. 2). The core stratigraphy from Ward and Baird (1954) is shown re-drawn in Figure $3(b)$. Their value for the 1952-53 net accumulation (0.43 $\mathrm{m}$ waterequivalent) is exactly the same as the 1949-79 average deduced from the present work.

The well-known cold years of 1972 and 1973, as well as the cool period 1949-53 are correctly reflected in the $\delta$ data (Fig. 4) and are confirmed by the stratigraphy (cooler periods are marked by less ice). Figure $3(b)$ shows that the first $6 \mathrm{~m}$ of the core is almost devoid of ice, indicating cool summers. Although Ward and Baird (1954) do not provide a chronology, it is probable that this period extends from 1945-53 (giving a mean net accumulation rate of about $\left.0.40 \mathrm{~m} \mathrm{a}^{-1}\right)$. The onset of heavy ice layering below $6.3 \mathrm{~m}$ would then logically correspond to the warmest period (1935-45) observed so far this century for most North American localities (Budyko, 1974; Mitchel1, 1961).

The cavities which occurred in the 1953 core are interesting, being evidently due to vertical creep of snow bridges spanning a crevasse. During warm summers, the presence of melt water would accelerate the deformation of the bridges. Subsequent winter snow would form cornices over the old iced bridges and a cavity would result. The $A-1$ core, allowing for the cavities, has a reduced length of $18.5 \mathrm{~m}$ and probably extends back to about 1922, which is near the heginning of the general warming period this century (Budyko, 1974). It is possible that in periods much warmer than the last 30 years, the $\delta^{18} 0$ record may not be so clear in

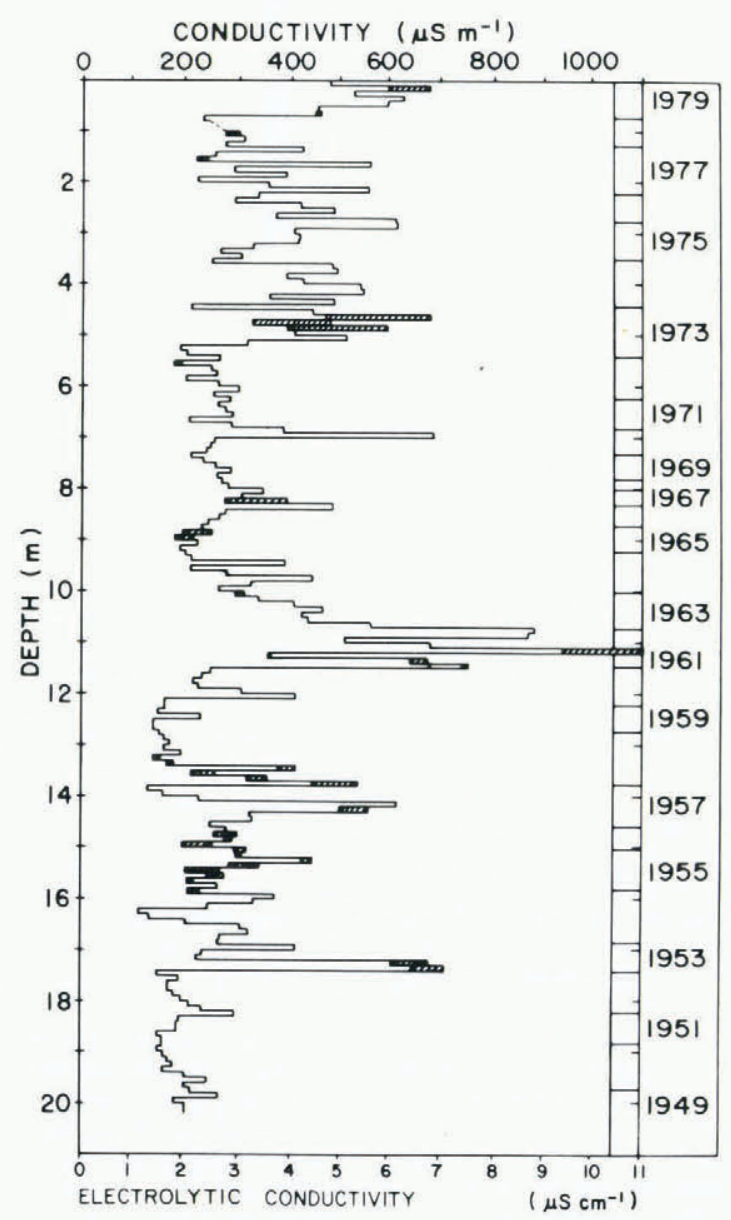

Fig.6. Electrolytic conductivity vamations with depth in the core. Values were determined using a Radiometer CDM3 conductivity meter. Shaded lengths represent the major differences in values between two independent determinations made using independently cut samples at $10 \mathrm{~cm}$ intervals on different quarter core lengths. Figure $8(a)$ shows a thind data set provided by an independent Laboratomy. Most major peaks in the well dated mid-core region appear to correspond to mid-year marks and this observation has been used in the lower core to help provide time control. 


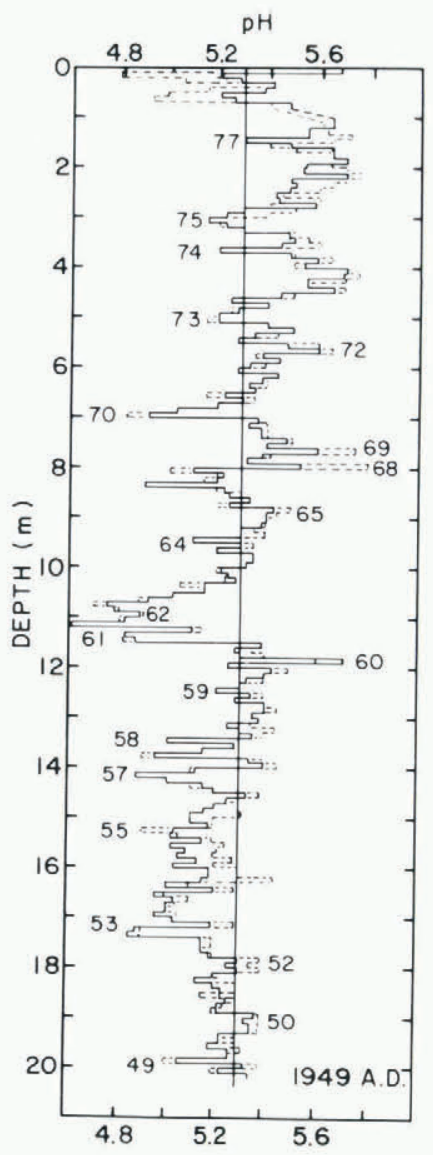

Fig.7. Depth vamiation of $\mathrm{pH}$ determined using a CANLAB H550 3-1 meter (dashed lines) and an Orion Research 407A pH meter (solid lines) on two independent sampling mins. Values apply at an atmosphemic pressure of $999 \mathrm{mbar}$ and a temperature of $20^{\circ} \mathrm{C}$. The major feature of this plot is a major acid peak at $11 \mathrm{~m}$ depth. This corresponds with the conductivity peak at the same depth (Fig. 6).

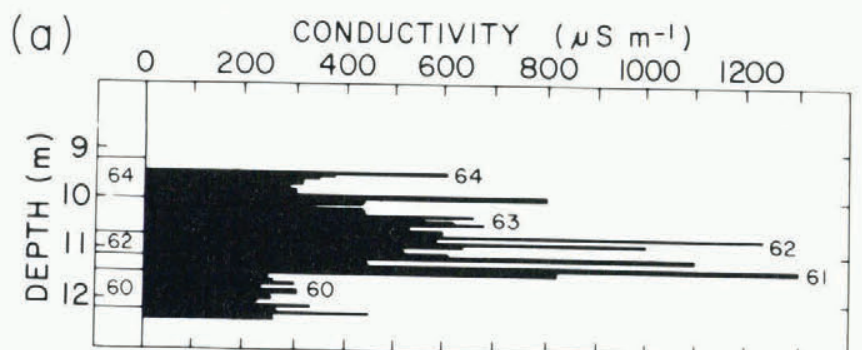

(b) NUMBER OF PARTICLES $\times 10^{3}$ LITRE $^{-1}$

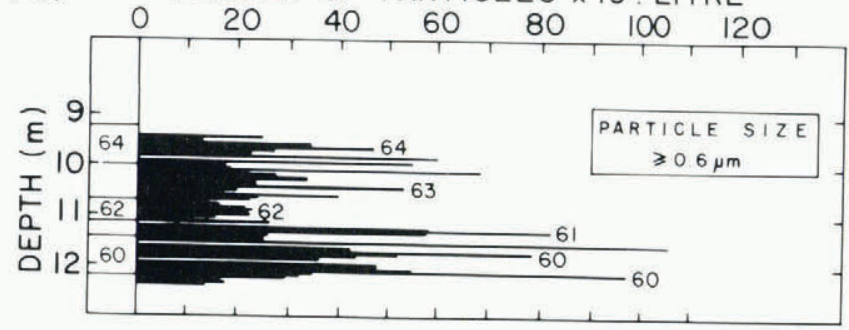

Fig.8. Conductivity (a) and particulate count (b) over the depth interval $9.5-12.5 \mathrm{~m}$. Sample intemal averages $5 \mathrm{~cm}$. At this cut length double peaks per year are apparent (time control from Fig. 5) (data from Polar Continental shelf Project Laboratory, ottawa). exhibiting significant seasonal variations. This would not, however, present an insurmountable problem in core interpretation. In a climatology section below, the correlation between the amount of ice in the core and the mean monthly maximum (July/August) temperatures will be discussed.

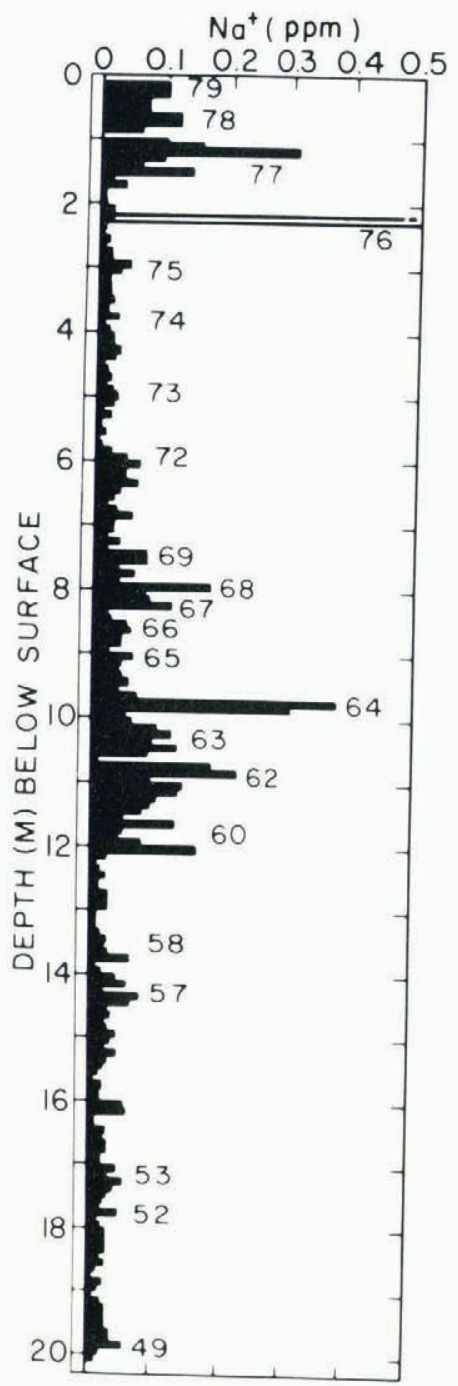

Fig.9. Concentration of $\mathrm{Na}^{+}$with depth. Shallow values (corresponding to pit samples) may be influenced by contamination. Values between 9.0 and $12.0 \mathrm{~m}$ are significantly higher than background levels but are thought to be real. Annual peaks (at about mid annual layer) seem to occur for greater than $2 / 3$ of the time span covered by the core. (Data: Enviroment Canada Laboratory: IL251 AA (flame) spectrophotometer).

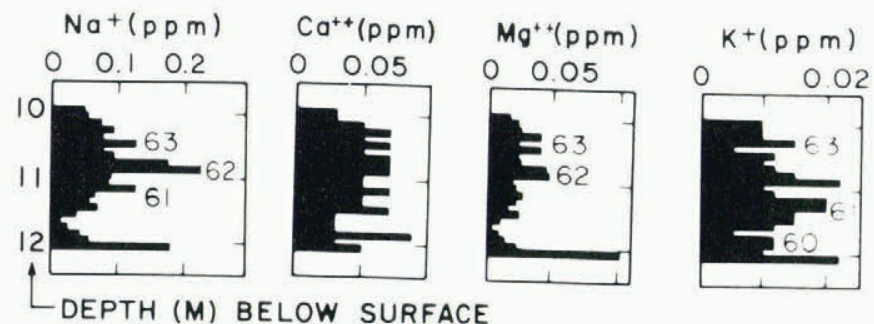

Fig.10. Concentrations of $\mathrm{Na}^{+}, \mathrm{K}^{+}, \mathrm{Ca}^{+}$, and $\mathrm{Mg}^{+}$ at $10 \mathrm{~cm}$ intervals between 10 and $12 \mathrm{~m}$, showing peaks, which in the case of $K^{+}$are predominantly annual (Data: Environment Canada Laboratomies). 


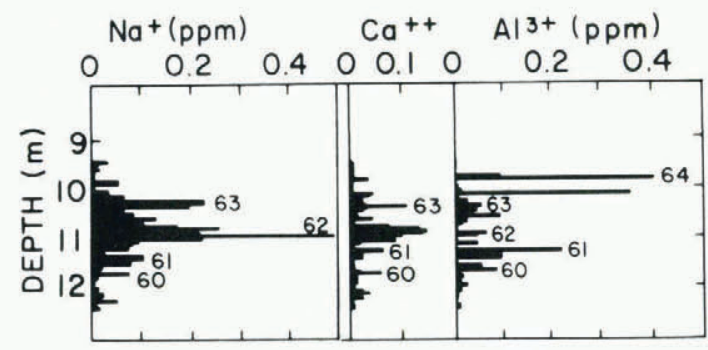

Fig.11. Concentration of $\mathrm{Na}^{+}, \mathrm{Ca}^{+}, \mathrm{Mg}^{+}$,

$\mathrm{Al}^{+}$, and $\mathrm{Si}^{+}$, between 9.5 and $12.5 \mathrm{~m}$.

Sampie intervals are approximately $5 \mathrm{~cm}$. Annual peaks are indicated using the time control estabZished (Fig. 5). Si $4^{+}$data shows the existence of double peaks per annual layer. This also occurs in the particulate data (Fig. 8(b)). (Data: Polar Continental shelf Project Laboratories: Perkin Elmer 603 graphite fumace AA spectrophotometer).

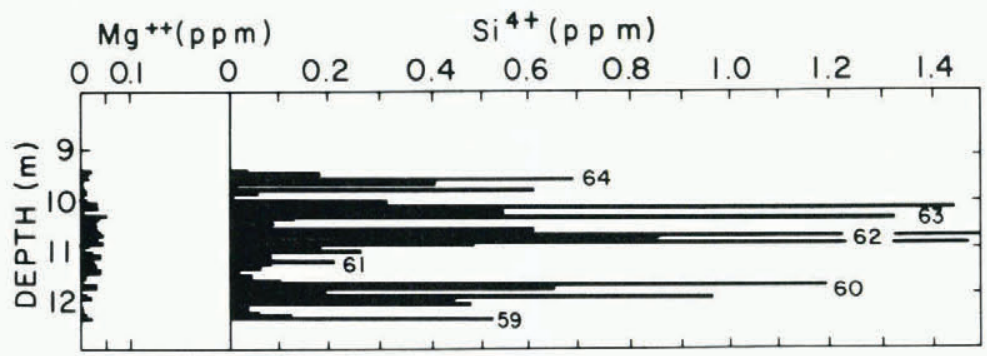

Electrolytic conductivity and $\mathrm{pH}$ measurements

The tritium results give an unambiguous 1963 date on ice just above the conductivity disturbance (see Fig. 6) at about $11 \mathrm{~m}$ depth. Any fallout from the large Mt Agung event would be expected to arrive in 1964. (There is a minor but significant conductivity peak at $9.5 \mathrm{~m}$ depth which corresponds to mid1964).

A possible source of the major disturbance in both the conductivity and the $\mathrm{pH}$ profiles, peaking in 1961 and 1962 and continuing through 1963, is northernhemisphere volcanism, which, according to recent records (Simkin and others, 1981), began a new active phase in the Pacific North-West in the early 1960's compared with generally low activity in the latter part of the previous decade. A similar pattern in conductivity and $\mathrm{pH}$ was found in a core from the Yukon Territory (G. Holdsworth, unpublished data) and these core data are correlated primarily with volcanic eruptions in continental Alaska, the Alaska Peninsula, the Aleutian Islands, Kamchatka Peninsula, and the Kurile Islands. In particular, Mt. Trident (lat. $58^{\circ} 14^{\prime} \mathrm{N}$; long. $\left.155^{\circ} 07^{\prime} \mathrm{W}.\right)$, which began a new series of major sulphurous emissions in 1961 (written communication from J. Kienle; Simkin and others, 1981) and continued through the sixties, is thought to be the main source of the conductivity and $\mathrm{pH}$ disturbance between $11.5 \mathrm{~m}$ and $10 \mathrm{~m}$ depth in the core. The electrolytic conductivity values shown in Figure $8(\mathrm{a})$ confirm the general features of the profile in Figure 6 .

\section{Particulate content of the core}

Figure 8 (b) shows dust peaks in the early 1960 's corresponding roughly with the conductivity peaks. Furthernore, there are double peaks, which occur about the middle of the year in each case. This type of distribution was found by Koerner (1977[b]) for the Devon Ice Cap core. Hammer (1977) has also found that particulates in ice cores peak at least once per year (and usually mid-year), so that annual layers may be identified by this method. Some of the work of Thompson (1977) also supports these observations.

\section{Core chemistry}

The common ion chemistry may be used to further interpret the core. From the base of the core to a depth of $2 \mathrm{~m}$, the background $\mathrm{Na}^{+}$concentration (Fig. 9) is close to ahout 0.02 p.p.m. with a significant departure from this level in the interval from about $12 \mathrm{~m}$ to about $6 \mathrm{~m}$. The highest concentrations are to be found between $12 \mathrm{~m}$ (1960) and $9.5 \mathrm{~m}$ (1964), the interval that broadly coincides with the anomalies in conductivity, $\mathrm{pH}$, and particulates. Moreover, certain $\mathrm{Na}^{+}$peaks in $1964(9.8 \mathrm{~m}), 1976(2.2 \mathrm{~m})$, and 1977 $(1.2 \mathrm{~m})$ also occur at the same dates as those in a $\mathrm{Na}^{+}$concentration profile for a core spanning 20 years obtained from the Agassiz Ice Field, Ellesmere Island (R.M. Koerner, unpublished data). This would seem to indicate, at least for some of the $\mathrm{Na}^{+}$fallout, that the two sites were receiving aerosols from the same source.

The consistently higher $\mathrm{Na}^{+}$levels in the upper $1.5 \mathrm{~m}$ could be due to contamination of the snow-pit samples, and therefore interpretation in this interval is avoided.

Annual layer identification

Seasonal or annual peaks in cation (and anion) concentrations have been recognized in firn cores (Langway and others, 1977; Busenberg and Langway, 1979) and can be used to determine the thickness of annual layers along the core. The established depthtime scale (Fig. 4) has been used to determine if seasonal (annual) variations in ionic species exist. The time annotations on Figures 8, 9, 10, and 11 show to what extent these variations can be recognized. The data obtained from the shorter sample length (approximately $5 \mathrm{~cm}$ ) is clearly superior to those obtained from the samples with an arbitrary length of $10 \mathrm{~cm}$. This indicates that for this work, at least eight samples per annual layer should be cut (Langway and others, 1977). Conductivity peaks and, to a less convincing degree, particulate concentration peaks occur approximately at the centre of an annual layer from 1960 to 1964 (Fig. 8).

Figures 9 and 10 show only weak annual signatures, with the more convincing signals being found in the $\mathrm{K}^{+}$concentrations. Figure 11 shows that some annual signatures exist in the $\mathrm{Na}^{+}, \mathrm{Ca}^{2+}, \mathrm{Al}^{3+}$, and $\mathrm{Si}^{4+}$ data. The latter, however, exhibit the best signatures with almost unambiguous peaks (or double peaks) occurring from 1959 to 1964 . The existence of the annual double peaks in both the particulate and the $\mathrm{Si}^{4+}$ concentration profiles is mutually consistent and may be useful in identifying annual layers in deeper core.

\section{PROXY CLIMATE INFORMATION DERIVED FROM THE CORE}

A functional relationship is assumed to exist between $\delta^{18} 0$ values and the corresponding air temperature at the time of precipitation (Dansgaard and others, 1973). This relationship might be extended to apply to annual means of individual values of $\delta$ and temperature. The data and time scale in Figure 4 may 


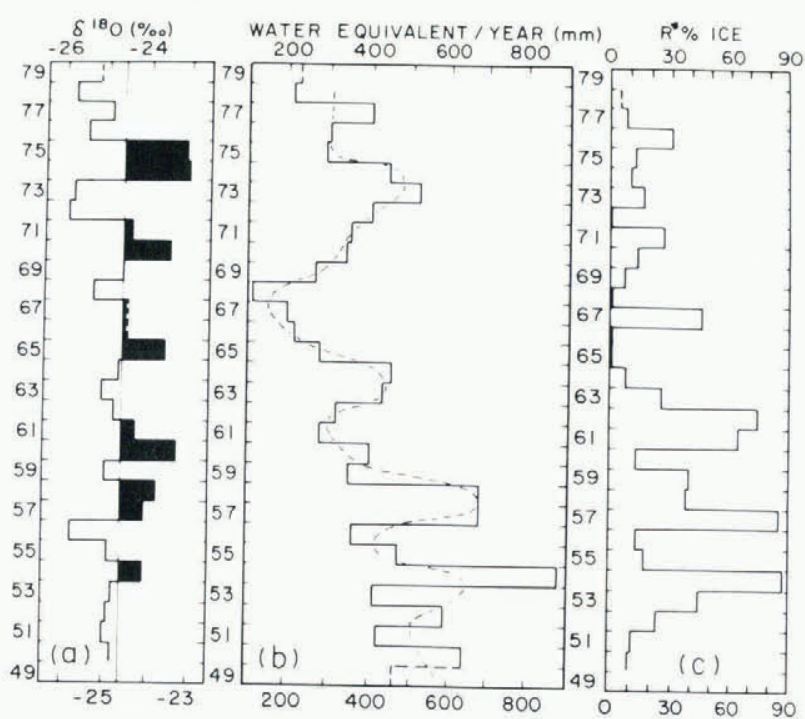

Fig.12. (a) Mean annual $\delta^{180}$ (unweighted)

1949-79; (b) net waterequivalent per year 1949-79; (c) percentage of melt-water ice per annual layer

in the core.

be used to compute $\bar{\delta}$, the mean annual values of $\delta$. If the precipitation pattern were roughly the same in each year (but not necessarily evenly distributed within a year) then this $\bar{\delta}$ time series might be expected to show some correlation with a mean (annual) temperature time series for the site, or in the absence of such data, with a corresponding temperature time series for the nearest climatological station.

Because the $\bar{\delta}$ values thus derived ( $F i g .12 a$ ) are naturally weighted in terms of the schedule of precipitation on the ice cap, it may appear unrealistic to attempt a direct correlation with mean annual air temperatures at instrumental stations along the coast (Fig. 1). Therefore, the mean annual temperatures for Broughton Island and Cape Dyer were recomputed by weighting mean monthly temperatures according to the monthly precipitation. This series yielded weaker cross-correlations with the ice cap $\bar{\delta}$ time series than the unweighted temperature time series. It could be concluded that the annual precipitation schedule on the ice cap is significantly different from the precipitation schedule at the nearest coastal stations. For this reason, no weighting has been applied to any of the time series.

Figure 13 a and $c$ shows the mean annual temperatures from 1960-79 for Cape Dyer and from 1959-79 for Broughton Island, respectively. Total annual precipitation for each station (Fig. 13 b,d) is also shown to indicate the great local variability in magnitude and time. Figure 13 e shows the much longer time series for mean annual temperature for Frobisher Bay, $300 \mathrm{~km}$ south-west of Pangnirtung (Fig. 1). Cross-correlation coefficients between the $\bar{\delta}$ time series and the time series of mean annual temperature (Fig. $13 \mathrm{a}, \mathrm{c}, \mathrm{e}$ ) are given in Table I. Cross-correlation coefficients between instrumental stations are seen to be high whereas the coefficients corresponding to the $\bar{\delta}$ series are low, even when using five-year running mean values. However, the fact that the coldest year (1972) in the last two decades and the cool period 1949-53 can be seen in the $\delta$ profile, suggests that extremes and longer-term trends might be seen in a longer time series.

Dansgaard and others (1973) give data on $\delta$ versus altitude for west mid-Greenland firn that indicate that the Penny Ice Cap snow (which has a three decadal mean of $-24.6^{\circ} / 00$ ) is slightly less depleted in $\mathrm{H}_{2}{ }^{18} 0$ than at the corresponding altitude $(c .2000 \mathrm{~m})$ in Greenland. The site in Greenland most comparable to the summit of Penny Ice Cap is Dye 2 which is slightly over $2000 \mathrm{~m}$ in altitude and has a mean annual fim temperature of $-16.7^{\circ} \mathrm{C}$ (Herron and Langway, 1980).

A mean annual air temperature for the Penny

TABLE I

CROSS-CORRELATION COEFFICIENTS BETWEEN TIME SERIES

$$
\text { Frobisher Bay }
$$

(MAT*)

Ice cap $\left(\delta^{18} 0\right)$
$\begin{aligned} & \text { Frobisher Bay } \\ & \text { (MAT) }\end{aligned}$
$\begin{aligned} & \text { Broughton Is. } \\ & \text { (MAT) }\end{aligned}$

Broughton Is.

(MAT)

$$
\begin{array}{ll}
0.284 \pm 0.436 & 0.278 \pm 0.448 \\
0.373 \pm 0.486 & 0.368 \pm 0.500 \\
& \\
0.874 \pm 0.436 & \underline{0.829 \pm 0.448}
\end{array}
$$$$
0.899 \pm 0.558
$$

pe Dyer (MAT)

Frobisher Bay MMDT $\phi$

$\begin{array}{ll}\begin{array}{c}\text { Ice cap } \\ \left(R^{\star} \text { ice }\right)\end{array} & 0.273 \pm 0.372 \\ & 0.460 \pm 0.384 \\ & \underline{0.747 \pm 0.400}\end{array}$

Frobisher Bay 1MUDT
Broughton Is
MMDT

$0.329 \pm 0.448$

$0.562 \pm 0.472$

$\underline{0.563 \pm 0.500}$

$0.505 \pm 0.436$
Cape Dyer
(MMDT)

$0.411 \pm 0.458$

$0.631 \pm 0.486$ $0.553 \pm 0.516$

$0.482 \pm 0.448$

$0.746 \pm 0.448$
(L)

Broughton Is. IIMDT

$R^{\star}$ ice $=$ percentage ice in core per annual layer

* MAT = Mean annual temperature; $\varnothing$ MMDT = Mean maximum daily (July) temperature Cross-correlation coefficients: $R(L) \pm 2$ standard deviations.

$L=$ length (years) of moving averages. All cases are for zero lag.

Underlined values are significantly different from zero at two standard deviations. 

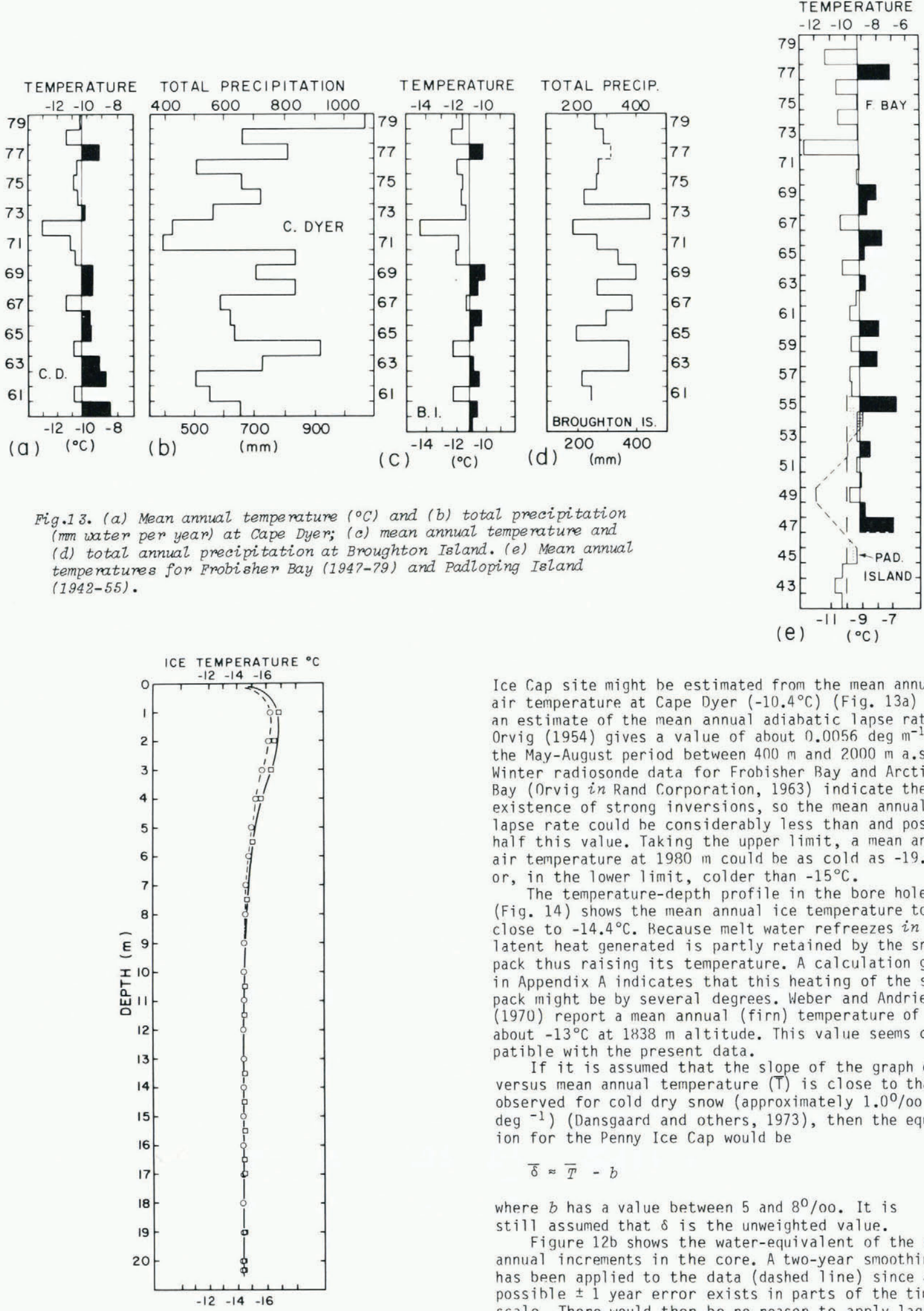

Fig.14. Temperatures measured in the bore hole on May 2 () and May 4 (0). Mean annual ice temperature is $-14 \cdot 4^{\circ} \mathrm{C}$.
Ice Cap site might be estimated from the mean annual air temperature at Cape Dyer $\left(-10.4{ }^{\circ} \mathrm{C}\right)(\mathrm{Fig} .13 \mathrm{a})$ and an estimate of the mean annual adiabatic lapse rate. Orvig (1954) gives a value of about $0.0056 \mathrm{deg} \mathrm{m}^{-1}$ for the May-August period between $400 \mathrm{~m}$ and $2000 \mathrm{~m}$ a.s.1. Winter radiosonde data for Frobisher Bay and Arctic Bay (Drvig in Rand Corporation, 1963) indicate the existence of strong inversions, so the mean annual lapse rate could he considerably less than and possibly half this value. Taking the upper limit, a mean annual air temperature at $1980 \mathrm{~m}$ could be as cold as $-19.6^{\circ} \mathrm{C}$ or, in the lower limit, colder than $-15^{\circ} \mathrm{C}$.

The temperature-depth profile in the bore hole (Fig. 14) shows the mean annual ice temperature to be close to $-14.4^{\circ} \mathrm{C}$. Because melt water refreezes in situ, latent heat generated is partly retained by the snowpack thus raising its temperature. A calculation given in Appendix A indicates that this heating of the snowpack might be by several degrees. Weber and Andrieux (1970) report a mean annual (firn) temperature of about $-13^{\circ} \mathrm{C}$ at $1838 \mathrm{~m}$ altitude. This value seems compatible with the present data.

If it is assumed that the slope of the graph of $\bar{\delta}$ versus mean annual temperature $(\bar{T})$ is close to that observed for cold dry snow (approximately $1.0 \%$ deg ${ }^{-1}$ ) (Dansgaard and others, 1973), then the equation for the Penny Ice Cap would be

$$
\bar{\delta} \approx \bar{T}-b
$$

where $b$ has a value between 5 and $8 \% / 00$. It is still assumed that $\delta$ is the unweighted value.

Figure $12 \mathrm{~b}$ shows the water-equivalent of the net annual increments in the core. A two-year smoothing has been applied to the data (dashed line) since a possible \pm 1 year error exists in parts of the time. scale. There would then be no reason to apply lags to the series before attempting to cross-correlate with other time series. It turns out that correlations between any of the precipitation time series (Figs $12 b$, $13 \mathrm{~b}$ and $d$ ) are hardly significant, although it is 
possible, visually, to connect some extreme events. This result is not unexpected since the series in Figure $12 \mathrm{~b}$ represents net accumulation and that in Figure 13 total accumulation, and because of the failure to improve temperature cross-correlations using precipitation-weighted temperature data.

The net accumulation values $1969-74$ have no correlation with specific net mass balance data given for nearby "Boas" Glacier (Weaver, 1975) for the same period. This indicates that mass-balance data taken from different glaciers and from different elevations in this area cannot be compared over these time spans.

Figure $12 \mathrm{C}$ shows the percentage $\left(R^{*}\right)$ of ice in each annual increment of the core. A relationship might be expected to exist between $R^{*}$ and the number of days during the summer when daily temperatures were at or above a value sufficient to cause surface melting. The parameter closest to conveying this information is the Mean Maximum Daily Temperature (MMDT) (computed for each month and puhlished in station climatological summaries). In this case the MMDT value is usually a maximum in July. Sometimes the August value is greater, in which case this value is taken. Figure 15 shows available time series of MMDT for Frobisher Bay, Cape Dyer, and Broughton Island, which have the best correlations with $R^{*}$ when data are smoothed by 3-5 year moving averages (Table I).

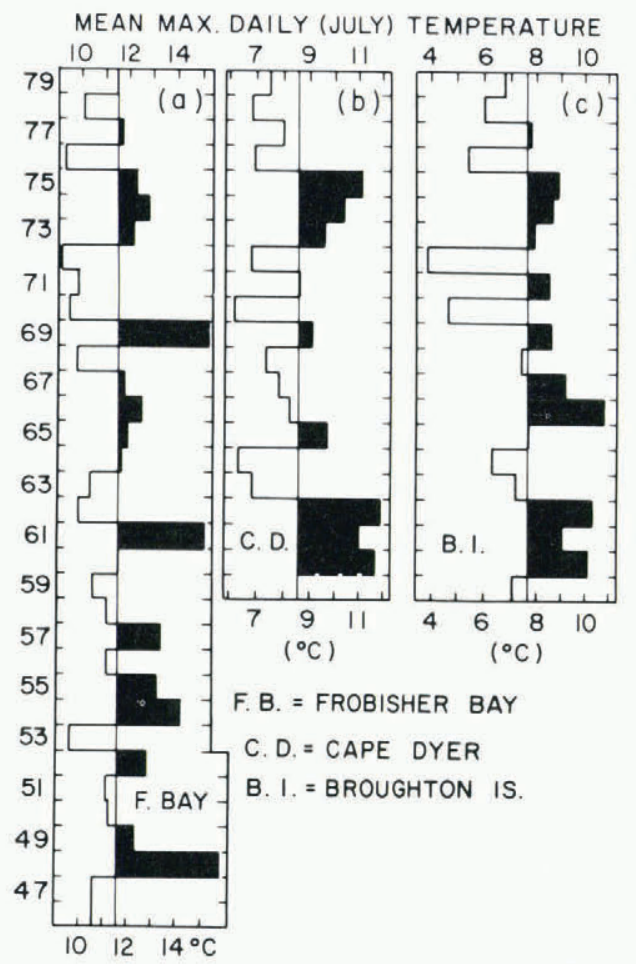

Fig.15. Mean maximum daily temperatures in July lor August, if greater) for Frobisher Bay, Cape Dyer, and Broughton Island. Values above the respective means are shown in black.

By analysing Baffin Island station records for the period 1960-69, Bradley and Miller (1972) found that generally, the "ablation" period (June-August) was becoming cooler, whereas the "accumulation" period (September-May) was becoming warmer by about the same amount $(2 \mathrm{deg})$. The data in Figure $12 \mathrm{c}$ seem to show a response to this, in that, if averaging is made over two-year intervals, there is an indication of decreasing ice in the firn over this period. The correlations between $R^{*}$ and station IMMT values are significantly higher than correlations between $\delta$ and MAT values

(Table I). These latter correlations might be improved by a weighting procedure applied to the $\delta$ 's based on knowing the precipitation regime on the ice cap.

\section{TEMPERATURE PROFILE IN THE BORE HOLE AND THE ICE CAP}

The temperature-depth profile (Fig. 14) shows temperature values measured by thermistors in early May, 1979. The $10-12 \mathrm{~m}$ firn temperature $\left(-14.4^{\circ} \mathrm{C}\right)$ is expected to be several degrees warmer than the mean annual air temperature at the site (Appendix A).

Assuming that the present $12 \mathrm{~m}$ temperature is approximately representative of the long-term value, that the average accumulation rate was approximately constant over the same period, that the divide has essentially been stationary, and that the ice thickness has been roughly constant over $10^{3}-10^{4}$ years, it is possible to estimate the basal temperature of the ice cap using a steady-state solution for an ice divide $($ Appendix $B)$. The result is that the basal ice temperature is well below freezing $\left(-9\right.$ to $\left.-10^{\circ} \mathrm{C}\right)$.

\section{ICE THICKNESS MEASUREMENTS}

Ice-cap thickness profiles were determined independently by surface and airborne operations in May 1979.

\section{Surface survey}

The surface measurements were made using the radar unit described by Goodman (1975). The equipment (operating at a frequency of $620 \mathrm{MHz}$ ) was moved by sled within a $1 \mathrm{~km}^{2}$ grid covering the divide ( $\mathrm{Fig}$. 16a). The time-amplitude spectra (A-scope trace) was observed on a Tektronics 422 oscilloscope. Excellent echoes, with steep fronts in most cases, were interpreted to be from the base of the ice cap (Fig. 16b). In some cases, intermediate echo pulses, partly obscured by the transmit pulse, could be detected at depths slightly greater than half the ice thickness (Fig. 16c). These pulses varied in shape and amplitude as the antenna orientation was changed. The bottom pulse was generally sharpest when the axis of the antenna was perpendicular to the ice divide. Basal return pulse travel times were between 5.5 and $6.2 \mu \mathrm{s}$ $( \pm 0.1 \mu \mathrm{s})$. Allowing for internal electronic delays

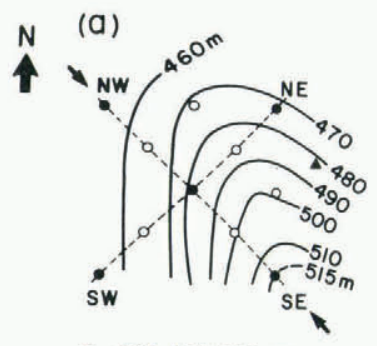

(b)

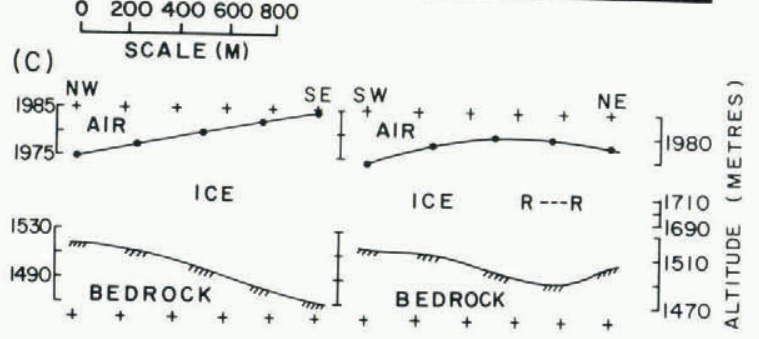

Fig.16. Radar depth results for the divide region: (a) Isopach map. The divide lies along the NW-SE line. (b) Typical A-scope trace showing transmitted pulse (T), an internal reflection ( $R$ ) and base reflection (B). (c) Surface and bedrock profiles along the $N W-S E$ and $N E-S W$ Zines. Reflector homizon $R-R$ corresponds to a depth of about $270 \mathrm{~m}$. Note different vertical scales used. 
and for the height of the antenna above the snow, and assuming an average electromagnetic wave speed of $168.5 \mathrm{~m} \mathrm{\mu s}^{-1}$ (Weber and Andrieux, 1970; Jones, 1972), total ice thicknesses are found to lie betwen 457 and $516 \pm 10 \mathrm{~m}$. Figure $16 \mathrm{a}$ shows the ice thickness map with two profiles given in Figure $16 \mathrm{c}$. Ice thickness is increasing towards the nearest dome to the southeast, a result that is confirmed by the results of the airborne survey.

\section{Airborne survey}

On 9 May a radar overflight was carried out. A C-130 aircraft, operated by the U.S. Navy VXE6 squadron in conjunction with the U.S. National Science Foundation and the Technical University of Denmark made a series of passes over the entire ice cap during a $7.5 \mathrm{~h}$ period. An inertial navigation system was used and the camp served as a navigation check point. Two transmitting frequences ( 60 and $300 \mathrm{MHz}$ ) were used simultaneously at a pulse width of 250 ns (giving a range resolution of $20 \mathrm{~m}$ ). Data have been supplied by Overgaard (unpublished) although only a small percentage of the total data are reproduced here. Figure 17 shows two cross-sections produced from the photographic record of the continuous Zscope traces for the divide area near the core site. Ice depths are seen to be in good agreement with the values determined using the surface equipment. Of particular significance are the existence of internal reflections seen at both frequencies. The reflecting horizons are not continuous nor of equal strength. Near the divide, a reflection was detected at a depth of about $270 \mathrm{~m}$ (Figs $16 \mathrm{~b}, \mathrm{c}$ and 17). This corresponds to a date of $940 \pm 50 \mathrm{~A}$.D. and may be a major volcanic or climatic time horizon. Gudmandsen (1975) has described similar reflecting layers for the Greenland Ice Sheet.

\section{A TIME-DEPTH SCALE FOR THE ICE CAP}

A number of assumptions must be made in order to estimate the age of the ice at a given depth. First, since the site is similar to Dye 2 (Herron and Langway, $1980)$, the firn-ice transition is assumed to be at $50 \pm 5 \mathrm{~m}$. Secondly, the vertical component of velocity at the surface is assumed to be constant and equivalent to the long-term accumulation rate. Thirdly, a steady-state ice thickness is assumed.

As an approximation, the observed form of the variation $v(z)$ of velocity with depth for Devon Ice Cap (Paterson, 1981, p. 70) has been used with the specific constraint that at depth $z=20 \mathrm{~m}, t=30 \mathrm{a}$. Equivalent empirical expressions for $v(z)$ for Penny Ice Cap are:

$$
\begin{array}{ll}
v(z)=0.187 \ln (1+z)+1.2 & 0 \leqslant z \leqslant 50 m, \\
v\left(z_{\mathrm{i}}\right)=V_{\text {is }}\left(1-z_{\mathrm{i}} / H_{\mathrm{i}}\right)^{m} & 50 \leqslant z \leqslant 480 \mathrm{~m} .
\end{array}
$$

Where $V_{\text {is }}$ is the ice equivalent vertical velocity at the ice equivalent surface of the ice cap, $z_{j}=z_{-} z_{0}$ which is the vertical distance measured from the pressent surface to the ice equivalent surface, $H_{i}$ is the ice equivalent thickness of the ice cap, $\left(H_{j}=H-z_{0}\right)$, and $m$ has a value of about 1.3 . The age at a given depth $\boldsymbol{z}$ is obtained from

$$
t=\int_{0}^{z} v(z)^{-1} \mathrm{~d} z
$$

The upper curve (1) meets the lower curve (2) at about $50 \mathrm{~m}$ (the firn-ice transition) where by integration of
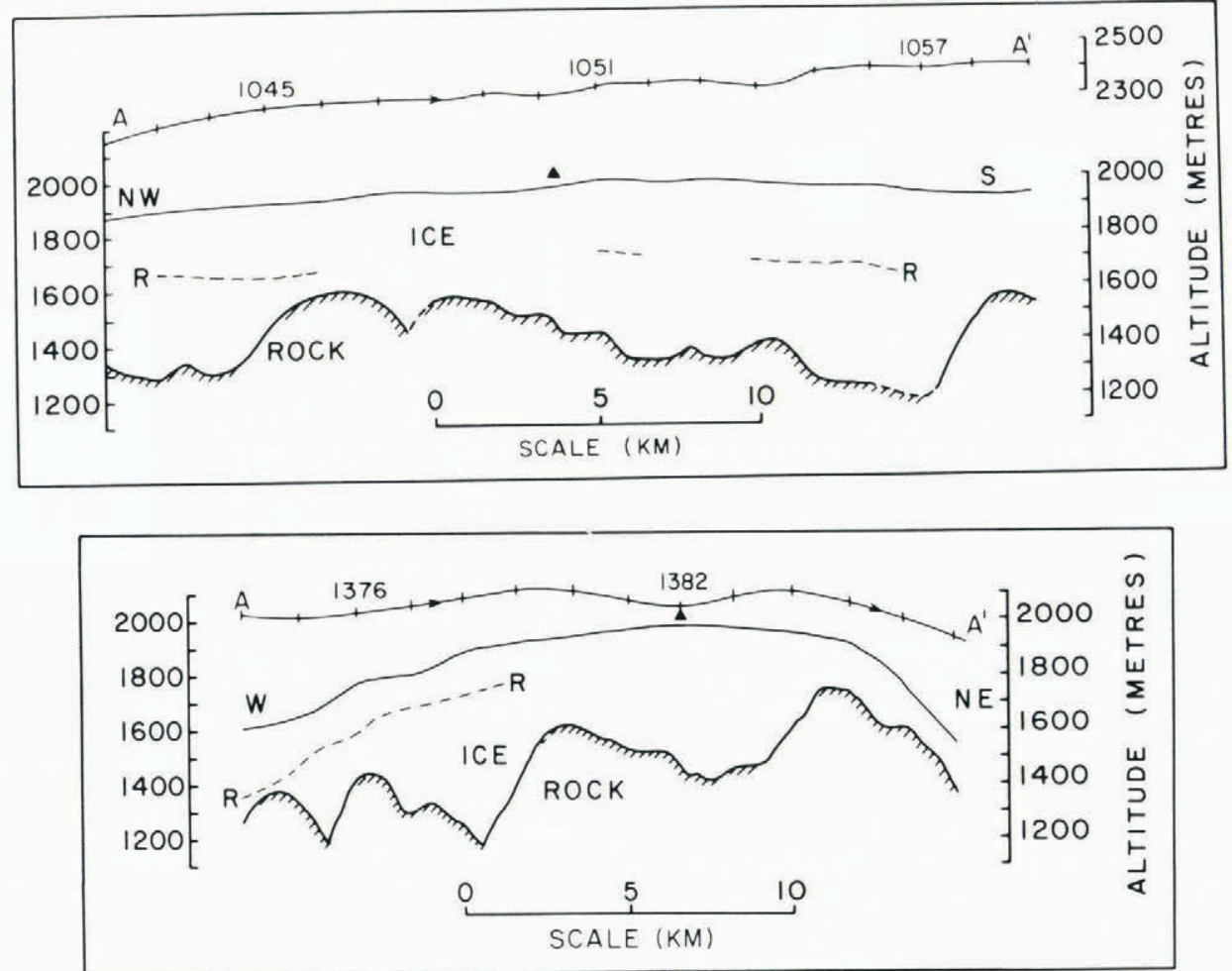

Fig.17. Snow-surface and bedrock profiles along two flight tracks approximately parailet and perpendicular to the axis of the ice cap (see Fig. 2). Reflector horizon $R-R$ corresponds approximately to the reflector horizon shown in Figure 16. Data obtained at $60 \mathrm{MHz}$ frequency. Profiles $A A^{\prime}$ represent aireraft flight tracks and numbers identify position of ai reraft and radar data. The black triangle marks the position of the core site and camp. 


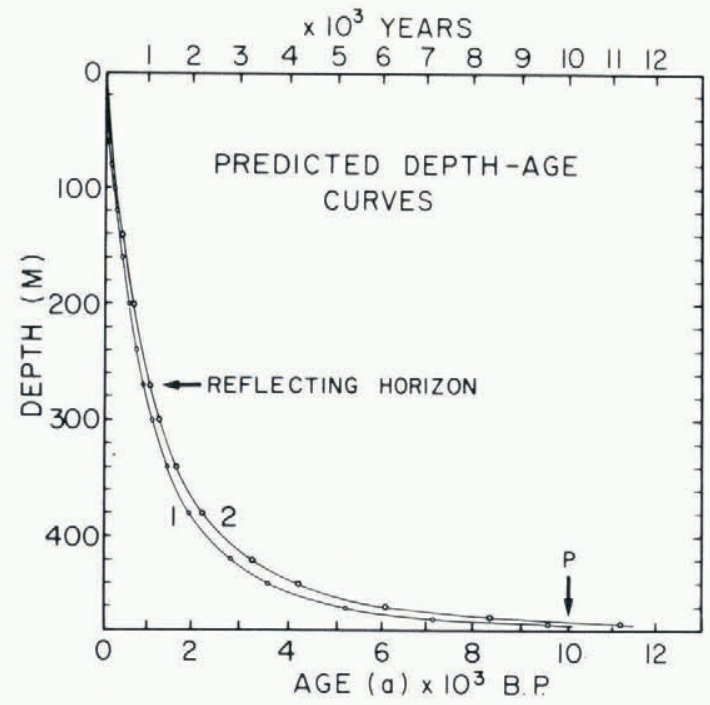

Fig.18. Predicted depth-age relationship for the divide site for a total ice thickness of $480 \mathrm{~m}$. Curve 1 corresponds to a uniform vertical velocity at the surface of $0.47 \mathrm{~m}^{-1}$; curve 2 to a vertical velocity of $0.4 \mathrm{~m} \mathrm{a}^{-1}$. The reflecting horizon at $270 \mathrm{~m}$ depth corresponds to an age of 1036 years on curve 2. Point $P$ marks the Holocene-Pleistocene boundary, for curve 1 at $5 \mathrm{~m}$ above the bed, and for curve 2 at $8 \mathrm{~m}$ above the bed.

(1) according to Equation (3) the age of a layer $(z=50)$ is about 88 years $( \pm 10 \mathrm{a})$. Taking $z_{0}=16 \mathrm{~m}$, and ignoring further densification, the age of the ice in the depth interval $50 \mathrm{~m}<z<480 \mathrm{~m}\left(34 \mathrm{~m}<z_{j}\right.$ $<464 \mathrm{~m}$ ) is:

$$
t\left(z_{\mathrm{i}}\right)=t_{z_{\mathrm{i}}=34}+\int_{34}^{z_{i}} V_{\mathrm{is}}^{-1}\left(1-z_{\mathrm{i}} / H_{\mathrm{i}}\right)^{-m} \mathrm{~d} z_{\mathrm{i}} .
$$

Figure 18 shows the predicted depth-time curves for $m=1.3$ and for two values of $v_{j}$. The first is equivalent to the present surface net balance and the second is about $14 \%$ less. The selected value of $m$ is thought to be very close to the one that best defines $v(z)$ for steady-state during essentially most of Hol ocene time. A value of $m \approx 1.25$ produces the best fit to the depth time scale for Devon Ice Cap (Paterson* and others, 1977). There, Paterson (1976) found that a surface velocity $v_{\mathrm{s}} 13.6 \%$ less than the presently observed net balance value best fitted the derived time-depth curve.

Corresponding to the major internal reflecting horizon at a depth of $270 \pm 10 \mathrm{~m}$ and for $v_{i s}=0.40 \mathrm{~m} \mathrm{a} \mathrm{a}^{-1}$, the most likely age is 943 A.D. \pm 50 a. This is seen to bracket the date of the massive Icelandic eruption of Eldgjă in $934 \pm 2$ A.D. which for central Greenland has an acidity signature far greater than any other event in the last 7600 years (Hammer and others, 1980). Millar (1982) refers to the recognition of a similar acid-volcanic reflecting horizon at Camp Century, Greenland, originally identified by Robin and others (1969). In addition, this depth-time curve shows that pre-Holocene ice should be encountered within $8 \mathrm{~m}$ above the base of the ice cap. This result is in accordance with the findings of Hooke (1976[b]) for the nearby Barnes Ice Cap. A comparison might also be made with the similarly cold-based Devon Ice Cap (Paterson and others, 1977) where pre-Holocene ice was penetrated about $5 \mathrm{~m}$ off the bottom. There, the total ice thickness was only $299 \mathrm{~m}$ compared with $480 \mathrm{~m}$ for Penny Ice Cap. Other, similar curves may be generated for different values of $v_{i s}$ and $m$.

The annual layer thickness $\lambda$ is another para- meter required. If $\lambda_{0}$ is the initial ice equivalent surface annual layer thickness, it may be shown that

$$
\lambda(z)=\lambda_{0} \exp \left\{\int_{0}^{t} \dot{\varepsilon}_{z}(z) \mathrm{d} t\right\}
$$

in which

$$
\dot{\varepsilon}_{z}(z)=\mathrm{d} v(z) / \mathrm{d} z=-\frac{m v_{\text {is }}}{H_{\mathrm{i}}}\left(1-z_{\mathrm{i}} / H_{\mathrm{i}}\right)^{m-1}
$$

is obtained from the velocity curve and a value of depth corresponding to $t$ is obtained from the depthtime curve (no. 2) (Fig. 18) or its analytical equivalent (Equation (4)). The depth at which $\lambda$ is thus reduced to $0.01 \mathrm{~m}$ lies at about $450 \mathrm{~m}$.

\section{CONCLUSIONS}

On the Penny Ice Cap divide a suitable site exists for retrieving a core which would cover the complete Holocene time period. The ice below about $450 \pm 5 \mathrm{~m}$ depth will have annual layers compressed to under $1 \mathrm{~cm}$ thickness. Pleistocene ice should be encountered at from 5 to $8 \mathrm{~m}$ above the bed. 0xygenisotope variations due to seasonal temperature changes appear to be locked into the ice, and by diffusion these oscillations will probably be erased in several thousand years (Johnsen, 1977).

The climate data to emerge from the core will require careful treatment. It is evident that the percentage ice $\left(R^{*}\right)$ per annual layer has a significant correlation with summer temperatures as Koerner (1977[a]) found for Devon Ice Cap. This information however is dependent on successfully identifying summer melt layers in the core, a task which becomes increasingly more difficult with depth. The relationship between oxygen isotope ratio and air temperature is not simple, although certain features characteristic of the last few decades of the Arctic climate may be recognized. In order to clarify this relationship a considerable amount of data processing would seem to be necessary.

\section{ACKNOWLEDGEMENTS}

I wish to acknowledge the efforts of Dr John T. Andrews in stressing the need for a coredrilling program on the ice cap. The help of Robert Redhead, superintendent of Auyuittuq National Park (Pangnirtung) and the cooperation of Andrew Theriault of the N.W.T. Government (Frobisher Bay) is kindly acknowledged. I am particularly thankful to John Glynn who accompanied and helped me in the field. For arranging a radar ice depth-sounding overfight, I wish to acknowledge the help of $\mathrm{Dr}$ P. Gudmandsen of the Technical University of Denmark (Copenhagen), Dr R. Cameron, U.S. National Science Foundation, and Dr R. Ramseier, Environment Canada. I am most grateful to Dr S. Overgaard for providing ice thickness data.

The oxygen-isotope analyses of ice-core samples were carried out at the Geophysical Isotope Laboratory (Copenhagen) under the direction of Dr W. Dansgaard. I am indebted to Dr D. Fisher for providing me with the final annotated $\delta^{18} 0$ values. The tritium analyses were carried out at the Radiation Protection Bureau (Ottawa) under the direction of Dr F. Prandt1 and D. Meyerhoff.

I thank Dr R. Koerner of the Polar Continental Shelf Project, Ottawa for performing particulate, chemical, and conductivity analyses on part of the core. Other chemical analyses were carried out by Martha Bowron and Dr Laura Johnson (Environment Canada). I thank Dr P. Cohen (Environment Canada) who planned and evaluated the statistical analyses made on the time series. Drs R. Koerner, J.R. Weber, D. H. Lennox,
and P.D. Baird kindly read and checked the manuscript. 
APPENDIX A. ESTIMATE OF THE AMOUNT OF HEATING OF THE SNOW PACK BY EXPULSION OF LATENT HEAT

In order to provide an estimate of the temperature mise in the snow (firn), and hence to find the differ ence between the mean annual air temperature and the mean annual firn (ice) temperature, due to freezing of melt water, a simplified model is used, in which a thin, infinite plane heat source is considered to exist at the surface of a semi-infinite solid. The equation of one-dimensional heat flow in the (downward) $z$ direction is taken to be:

$$
\partial T^{\prime} / \partial t=\kappa \partial T^{\prime 2} / \partial z^{2}
$$

where $T^{\prime}$ is the temperature rise (or perturbation) above the ambient state without latent heat generation, $t$ is time and $k$ is the thermal diffusivity of the snow.

A solution of Equation (A1) for the above model is:

$$
T^{\prime}=(4 \pi \kappa t)^{-\frac{1}{2}} Q(\rho c)^{-1} \exp \left(-z^{2} / 4 \kappa t\right)
$$

for the case of a plane heat source $Q$ per unit area at $z=0$. The density of the snow is $\rho$ and its heat capacity $c$. In reality, heat $Q$ is generated within the first $1 \mathrm{~m}$ snow depth. For modelling purposes heating shall be considered to take place within the thin layer at the surface, but initially with all the heat transfer downwards. This imposes an upper limit on the estimated temperature rise in the firn (and hence in the ice lower down). It was determined that $25 \%$ of the annual snow layer was converted into ice on average. If snow at density $\rho$ is now converted to ice of density $\rho_{j}$ then the total heat released in the refreezing of the water is approximately $\left(\rho_{j}-\rho\right) \times$ $0.25 \mathrm{~L} \mathrm{~J} \mathrm{~m}^{-2}$ where $L$ is the latent heat of fusion $\left(3.34 \times 10^{5} \mathrm{~J} \mathrm{~kg}^{-1}\right)$. The heat thus released is $Q=4.5 \times 10^{7} \mathrm{~J} \mathrm{~m}^{-2}$. Equation (A2) is now evaluated at $z=0$ for $t=1$ a, to yield $T \approx 3.9^{\circ} \mathrm{C}$.

This process is an annual event, thus the mean annual firn (ice) temperature will be consistently warmer than the mean annual air temperature by about $4^{\circ} \mathrm{C}$. If half the heat is lost vertically upwards then the temperature difference will only be about $2^{\circ} \mathrm{C}$.

The actual difference is likely to lie between these limits.

This estimate is consistent with the estimates of Hooke (1976[a]) for the Barnes Ice Cap divide.

\section{APPENDIX B. STEADY-STATE TEMPERATURE DISTRIRUTION} THROUGH AN ICE DIVIDE

A solution for the temperature distribution below a divide in a model ice sheet was given by Robin (1955). In the model, a constant vertical strain-rate was assumed throughout. Such a vertical strain-rate distribution is not consistent with a cold-based glacier and the computed basal temperatures tend to be colder than observed, where data are available. For thin ice caps, the discrepancy is not serious (0.6 deg for a thickness of $500 \mathrm{~m}$ ) but for thicker ( $>1000 \mathrm{~m}$ depth) ice sheets the discrepancy may reach several degrees.

An expression for the vertical flow rate through the divide was obtained previously (Equation (2)). Substituting this into the original heat-flow equation (e.g. Paterson, 1981, equation (16)) the following equation is obtained after some simplification:

$$
\mathrm{d}^{2} T / \mathrm{d} z_{\mathrm{i}}^{2}-\left(v_{\mathrm{is}} / \kappa\right)\left(1-z_{\mathrm{i}} / H_{\mathrm{i}}\right)^{m} \mathrm{~d} T / \mathrm{d} z_{\mathrm{i}}=0
$$

Where $T$ is temperature, $v_{j}$ is the equivalent vertical velocity of the ice surface, $k$ is the thermal diffusivity of the ice, $H_{j}$ is the equivalent ice thickness, and $z_{i}$ is depth measured downwards from the surface.

Using the boundary conditions

$$
T=T_{\mathrm{s}} \text { at } z_{\mathrm{i}}=0
$$

and $\mathrm{dT} / \mathrm{d} z_{j}=\mathrm{G}=$ the geothermal gradient at $z_{j}=H_{j}$ and putting $a=v_{i s} / k$, the depth at temperature $z_{j}$ is then given by:

$$
T\left(z_{\mathrm{i}}\right)=T_{\mathrm{s}}+G \int_{0}^{z_{i}} \exp \left[\left(-a H_{\mathrm{i}} /(m+1)\right)\left(1-z_{\mathrm{i}} / H_{\mathrm{i}}\right)^{m+1}\right] \mathrm{d} z_{\mathrm{i}}
$$

For $m=1$, this equation reduces to the Robin (1955) solution, and may be evaluated in terms of the error function. Numerical solutions of Equation (B2) recast in the incomplete gamma function form, for a range of values of $a, H_{i}$, and $m$ for steps of $0.1<z_{j} / H_{i}<1.0$ have been obtained. Using values of $v_{j s}=0.40 \mathrm{~m} \mathrm{a}^{-1}$, $\kappa=36 \mathrm{~m}^{2} \mathrm{a}^{-1}, m=1.3, G=0.019 \pm 0.004 \mathrm{deg} \mathrm{m} \mathrm{m}^{-1}$, $T_{\mathrm{S}}=14.4^{\circ} \mathrm{C} \pm 1 \mathrm{deg}$ and $H_{j}=464 \pm 10 \mathrm{~m}$, the basal temperature is about $-9.1 \pm 2{ }^{\circ} \mathrm{C}$. More sophisticated modelling is possible (Paterson and Clarke, 1978) when deeper data are obtained.

\section{REFERENCES}

Andrews, J.T., and Barry, R.G. 1972. Present and paleo-climatic influences on the glacierization and deglacierization of Cumberland Peninsula, Baffin Island, N.W.T., Canada. University of Colorado. Institute of Arctic and Alpine Research. Occasional Paper No.2.

Andrews, J.T., and others. 1980. Holocene climate based on pollen transfer functions, eastern Canadian Arctic, by J.T. Andrews, W.N. Mode, and P.T. Davis. Aretic and Alpine Researeh, Vol. 12, No. 1, p. 41-64.

Baird, P.D., and others. Baffin Island expedition, 1953: a preliminary field report, by P.D. Baird [and 11 others]. Aretic, Vol. 6, No. 4, p. 227-51.

Barry, R.G., and Fogarasi, S. 1968. Climatology studies of Baffin Island, Northwest Territories. Canada. Dept. of Energy, Mines and Resources. Inland Waters Branch. Technical Bulletin No. 13.

Bradley, R.S., and Miller, G.H. 1972. Recent climatic change and increased glacierization in the eastern Canadian Arctic. Nature, Vol. 237, No. 5355, p. 385-87.

Budyko, M.I. 1974. Izmeneniya klimata. Leningrad, Gidrometeoizdat. [English translation: Climatic changes. Washington, D.C., American Geophysical Union, [C1977].]

Rusenberg, E., and Langway, C.C. jr. 1979. Levels of ammonium, sulfate, chloride, calcium, and sodium in snow and ice from southern Greenland. Joumal of Geophysical Research, Vol. 84, No. C4, p. 1705-09.

Dansgaard, W., and others. 1973. Stable isotope glaciology, by W. Dansgaard, S.J. Johnsen,

H.B. Clausen, and N. Gundestrup. Meddelelser om Grinzand, Bd. 197, $\mathrm{Nr} .2$.

Dansgaard, W., and others. 1975. Climatic changes, Norsemen, and modern man, by W. Dansgaard, S.J. Johnsen, N. Reeh, N. Gundestrup, H.B. Clausen, C.U. Hammer. Nature, Vol. 255, No. 5503, p. 24-28.

Dyke, A.S., and others. 1982. Quaternary geology of Cumberland Peninsula, Baffin Island, District of Franklin, by A.S. Dyke, J.T. Andrews, and G.H. Miller. Canada. Geological Sumey. Memoir No. 403.

Goodman, R.H. 1975. Radio echo sounding on temperate glaciers. Joumal of Glaciology, Vol. 14, No. 70, p. 57-69.

Gudmandsen, P. 1975. Layer echoes in polar ice sheets. Joumal of Glaciology, Vol. 15, No. 73, p. 95-101. 
Hammer, C.U. 1977. Dating of Greenland ice cores by microparticle concentration analyses. [Union Géodēsique et Géophysique Internationale. Association Internationale des Sciences Hydrologiques. Cormission des Neiges et Glaces.] Symposium. Isotopes et impuretés dans les neiges et glaces. Actes du colloque de Grenoble, août/septembre 1975, p. 297-301. (IAHS-AISH Publication No. 118.)

Hammer, C.U., and others. 1980. Greenland ice sheet evidence of post-glacial volcanism and its climatic impact, by C.U. Hammer, H.B. C.1 ausen, and W. Dansgaard. Nature, Vol. 288, No. 5788, p. 230-35.

Herron, M.M., and Langway, C.C., jr. 1980. Firn densification: an empirical model. Joumal of Glaciology, Vol. 25, No. 93, p. 373-85

Hooke, R.L. 1976[a] . Near-surface temperatures in the superimposed ice zone and lower part of the soaked zone of polar ice sheets. Joumal of Glaciology, Vol. 16, No. 74, p. 302-04. [Abstract.]

Hooke, R.L. 1976[b]. Pleistocene ice at the base of the Barnes Ice Cap, Baffin Island, N.W.T., Canada. Joumal of Glaciology, Vol. 17, No. 75, p. 49-59.

Jacobs, J.D., and others. 1974. Studies of climate and ice conditions in eastern Baffin Island, 1971-73 [by] J.D. Jacobs, R.G. Barry, R.S. Bradley, and

R.L. Weaver. University of Colorado. Institute of Aretic and Alpine Research. Occasional Paper No. 9.

Johnsen, S.J. 1977. Stable isotope homogenization of polar firn and ice. [Union Géodésique et Géophysique Intemationale. Association Intermationale des Sciences Hydrologiques. Commission des Neiges et Glaces.] Symposium. Isotopes et impuretés dans les neiges et glaces. Actes du colloque de Grenoble, aout/septembre, 1975, p. 210-19. (IAHS-AISH Publication No. 118.

Jones, S.J. 1972. Radio depth-sounding on Meighen and Bames Ice Caps, Aretic Canada. Ottawa, Environment Canada. Water Resources Branch. Inland Waters Directorate. (Scientific Series No. 25.)

Koerner, R.M. 1977[a]. Devon Island ice cap: core stratigraphy and paleoclimate. Science, Vol. 196, No. 4285 , p. 15-18.

Koerner, R.M. 1977[b]. Distribution of microparticles in a 299-m core through the Devon Island ice cap, Northwest Territories, Canada. [Union Géodésique et Géophysique Intermationale. Association Inter nationale des Sciences Hydrologiques. Commission des Neiges et Glaces.] Symposium. Isotopes et impuretés dans les neiges et glaces. Actes du colloque de Grenoble, août/septembre 1975, p. 371-76. (IAHS-AISH Publication No. 118.)

Koerner, R.M., and Fisher, D.A. 1982. Acid snow in the Canadian high Arctic. Nature, Vol. 295, No. 5845, p. $137-40$.

Koerner, R.M., and Taniguchi, H. 1976. Artificial radioactivity layers in the Devon Island ice cap, Northwest Territories. Canadian Joumal of Earth Sciences, Vol. 13, No. 9, p. 1251-55.

Langway, C..C., jr, and others. 1977. Seasonal variations of chemical constituents in annual layers of Greenland deep ice deposits, [by] C.C. Langway, Jr., G.A. Klouda, M.M. Herron and J.H. Cragin. [Unión Géodésique et Géophysique Intemationale.

Association Intemationale des Sciences Hydrologiques. Commission des Neiges et Glaces.] Symposium. Isotopes et impuretés dans les neiges et glaces. Actes du colloque de Grenoble, août/septembre 1975, p. 302-06. (IAHS-AISH Publication No. 118.)

Millar, D.H.M. 1982. Acidity levels in ice sheets from radio echo-sounding. Annals of Glaciology, Vol. 3, p. 199-203.
Miller, G.H. 1973. Late Quaternary glacial and climatic history of northern Cumberland Peninsula, Baffin Island, N.W.T., Canada. Quatemary Research, Vol. 3, No. 4, p. 561-83.

Mitchell, J.M. 196i. Recent secular changes of global temperatures. Annals of the New York Academy of Sciences, Vol. 95, No. 1, p. 235-50.

Orvig, S. 1954. Glacial-meteorological observations on icecaps in Baffin Island. Geografiska Annaler, Arg. 36, Ht. 3-4, p. 193-318.

Overgaard, S. Unpublished. Radio echo sounding data from Penny Icecap of 9 May 1979. [Electromagnetics Institute, Technical University of Denmark, Lyngby,
Report AR82, 1980.]

Paterson, W.S.B. 1976. Vertical strain-rate measurements in an Arctic ice cap and deductions from them. Joumal of Glaciology, Vol. 17, No. 75, p. 3-12.

Paterson, W.S.B. 1981. The physics of glaciers. Second edition. Oxford, etc., Pergamon Press. (Pergamon International Library.)

Paterson, W.S.B., and Clarke, G.K.C. 1978. Comparison of theoretical and observed temperature profiles in Devon Island ice cap, Canada. Geophysical Joumal of the Royal Astronomical Society, Vol. 55, No. 3 , P. 615-32.

Paterson, W.S.B., and others. 1977. An oxygen-isotope climatic record from the Devon Island ice cap, Arctic Canada, [by] W.S.B. Paterson [and 7 others]. Nature, Vol. 266, No. 5602, p. 508-11.

Rand Corporation. 1963. A report on the physical envi monment of S. Baffin Island, N.W.T., Canada. Santa Monica, California, Rand Corporation. (Rand Corp. Memorandum RM-2361-1-PR.)

Robin, G. de Q. 1955. Ice movement and temperature distribution in glaciers and ice sheets. Joumal of Glaciology, Vol. 2, No. 18, p. 523-32.

Robin, G. de Q., and others. 1969. Interpretation of radio echo sounding in polar ice sheets, by G. de Q. Robin, S. Evans, and J.T. Bailey. Philosophical Transactions of the Royal Society of London. Ser. A, Vol. 265, No. 1166, p. 437-505.

Simkin, T., and others. 1981. Volcanoes of the world: a regional directory, gazetteer, and chronology of volcanism during the last 10,000 years, [by] T. Simkin, L. Siebert, L. MeClelland, D. Bridge, C. Newhali, J.H. Latter. Stroudsburg, Pennsylvania, Hutchinson Ross Publishing Co.

Thompson, L.G. 1977. Variations in microparticle concentration, size distribution, and elemental composition found in Camp Century, Greenland, and Byrd Station, Antarctica, deep ice cores. [Union Géodésique et Géophysique Intemationale. Association Intemationale des Sciences Hydrologiques. Commission des Neiges et Glaces.] Symposium. Isotopes et impuretés dans les neiges et glaces. Actes du colloque de Grenoble, août/septembre 1975, p. 351-64. (IAHS-AISH Publication No. 118.)

Ward, W.H., and Baird, P.D. 1954. Studies in glacier physics on the Penny Ice Cap, Baffin Island, 1953. Part I. A description of the Penny Ice Cap, its accumulation and ablation. Joumal of Glaciology, Vol. 2, No. 15, p.342-55.

Weaver, R.L. 1975. "Boas" Glacier (Baffin Island, N.W.T., Canada) mass balance for the five budget years 1969 to 1974. Arctic and Alpine Research, Vol. 7, No. 3, p. 279-84.

Weber, J.R., and Andrieux, P. 1970. Radar soundings on the Penny Ice Cap, Baffin Island. Joumal of Glaciology, Vol. 9, No. 55, p. 49-54. 